\title{
Emerging Profile of Commerce and Management Education in India
}

\author{
Dr. M.M. Gandhi \\ Principal, Professor and Head PG Department of Commerce and Management, Jaysingpur College of Arts, \\ Commerce, Science and Computer Science (UG \& PG) A/post Jaysingpur - 416 101, Dist. Kolhapur, \\ Maharashtra
}

\begin{abstract}
This paper emphasizes that Business and Commerce are performing arts requiring inculcation of professional operative skills. However, every art and skill requires scientific knowledge as basic foundation in theory. Acquisition of theoretical knowledge sharpens human faculties of mind and intellect. Thus, a system of business and commerce education should equip the student with the knowledge of theory which he should apply in performing and practicing art, and getting knowledge from experience. A person should be made capable of thinking independently and should not depend on borrowed concepts or thorough. Similarly, he should develop a problem - oriented approach based on experience and not on a study of hypothetical situation. The paper stresses that training in applied business-science is a part of social responsibility of business.

Business and Commerce education should be oriented to the practical problematic micro and macro situation. This orientation would enable a commerce graduate or a business graduate to meet several challenging situations in managerial decision-making.

The paper emphasizes that commerce and business graduates must imbibe the fundamentals of language, logic, simple mathematics and business communication skills which create the power to think logically and present the problem in a lucid language. It is necessary to adopt an integrated approach which assumes that management of business and commerce should not be increasingly divided.

The paper concludes that emphasis in business and commerce education should be on total personality against the Government policies creating uncertainty and difficulties created by bureaucracy. Education in business and commerce should create a personality which is not only adaptable but of a high moral character. While keeping in line with the developments in technology and computerization, basic social and Indian values, Indian culture and tradition and typical problematic situations which are Indian should never be lost sight of, while imparting business and commerce education in India.
\end{abstract}

Keywords: Business and Commerce Education, managerial economics, performing art, skill, employability, HRD, ICT, research, training, extension work, performance appraisal.

\section{Introduction}

Basically, education in business is education in managerial economics. Business and commerce are performing arts. However, acquiring a skill requires some basic foundation in theory. Digesting a theory sharpens the human faculties of mind and intellect which enable a person to think independently with freedom from borrowed thoughts. The applied aspect of Business Management should be hypothetical as well as based on experience which a person may get by undergoing on-the-job apprenticeship training which is again the responsibility of business to provide. Imparting of such apprenticeship training in applied business science is a part of social responsibility of business. It is a dimension to the center prevalent business philanthropy, e.g. one can imagine Telco financing and running training and making aspiring but inexperienced people aware of the fundamental micro and macro situations which create several challenges in managing a business.

Though, business secrets need not be disclosed, instruction in fundamentals of language, logic and simple mathematics can be provided in an atmosphere where the principles are applied to gain practical experience. Moreover, a business unit imparting instruction and conducting training need not commit that the persons so trained in managerial economics and managerial skills be absorbed in the business unit itself. This is a philanthropic work in Human Resource Development for other industries which face various problems at the stages of promotion, survival and development.

\section{Awareness About The Challenges}

Today, management is becoming increasingly divided. There are those who are sticking with and are stuck with the ways that used to assure top performance and profits. And there are those who have learned to employ personal styles and professional strategies that satisfy the demands of a maturing corporate world and the technology, economy and society of today. 
Based on the experiences and lessons of leading corporations all over the world, THE MANAGERIAL CHALLENGE is designed to give every executive a clear understanding of the problem areas and the possible paths to success in today's changing business world, such as :

(a) Matching the job to the individual;

(b) Objective performance appraisals;

(c) Acquisition of skills, training and role of the Manager;

(d) Negotiation and managing;

(e) Management with emerging trends in Information and Communication Technology;

(f) Multinational business.

In the developing economy of India, the challenges are created and aggravated because of the uncertain and tricky Government policies and the beaurocracy. The whole system works in an atmosphere of uncertainty which is man-made rather than nature. If business and commercial activities amount to risk-taking; i.e., decision making against uncertainty, then such business education as would enhance the operative skills and adaptability of human character would be necessary.

Adaptability for character-building and image-building is a quality that can be achieved through formal education and experience gained through involvement in problematic situations. Thus, the orientation of business education in future is a maneuver. Adaptable personality is a personality which is oriented to finding out solutions to problems rather than problems to solve. This is possible when the process of teaching, learning and research are grass-rooted, have relevance to the local political problems.

Basically, there is a problem of Indianisation of business education with reference to the culture of a business unit, the social culture, the value system and the basic ethics. After formal learning, the individual should get the necessary exposure to the social and economic systems which are genuinely Indian. Business education should enable creation of awareness among individuals about the different developments around, which are the result of policy changes at the macro and micro levels. When such awareness is created the apologetic tendencies in human behaviour, fear-complex and frustration can be removed. Therefore, the basic objective of business education is to inculcate such habits, as would develop the free enlightened personality prepared to face various economic challenges without apology. The basis of such a personality is character having no fear-complex of nay kind.

Business education is not a matter of formal training brought about by a set process of learning and teaching. Learning from experience and developing positive values and attitudes should be the outcome of business educational system. Ability to criticize without being cynic, ability to get exposure without being a hypocrite and adaptability to face the old and new challenges without indulging in ugly compromises are the aspects of personality development for businessmen. Such a character building through business education is necessary for HRD which is fundamental to any developed or developing country. A man, who has acquired business skills through business education, is an asset to the society, because through the communication and leadership skills acquired, he can remove the forces which create a hurdle in building up a harmonious society. Basically an educated mind is the powerful force behind development of a spirited individual and the society.

\section{Conclusion}

I would end my paper with the objectives of training in business management quoted by the Indian Institute of Management, A'bad (IIMA) : "Training for management extends beyond the frontiers of formal education in humanities scientific and engineering disciplines (and) is of quite recent awareness in India. It is understandably the obvious first priority in development to think of means of production and the next of these men with the requisite skills, the engineers, chemists and accountants. But for the operation to work at more than its optimum efficiency these men need the wider operation and the attitude and the philosophy that take the organization forward". To quote from the objectives outlined by the Institute of Management, Bangalore: "Training for Management aims at augmenting the nation's management resources through programmes of study, research, training and extension work. In addition to contributing to the traditional areas of management, it lays emphasis especially on the management needs of the public sector and those socially relevant sectors of activity which have not as yet had systematic exposure to modern management inputs. Sectors taken up so for are the Agriculture and rural development, education, energy and power habitant, population and health and transportation."

\section{References}

[1]. Anchison T J, Hill WW, 'Management Today', Harcourt Brace Jovanovich, Inc., 1978;

[2]. Brahmankar Dr. AB, 'Commerce and Business Education, some thoughts' (Marathi), Sunita pub., Nashik, 1986;

[3]. Chugh KL, 'Managing Change' his speech as Chairman, at the $43^{\text {rd }}$ Annual General Meeting of Tribeni Tissues, Ltd., Calcutta, advt. Indian Express, July 14, 1990, p10;

[4]. Drucker PF, 'Management : Tasks, responsibilities, Practices', W. Heinemann Ltd., London, 1974; 
[5]. Booklets etc., on - 'Apprenticeship, Management Training Scheme', - By Industries in Pune;

[6]. Louden JK, 'Managing at the top', Amacon, New York, 1977;

[7]. McAlpine TS, 'The Process of Management', Business Books Ltd., London, 1973;

[8]. Morvin Phlip, 'Multiplying Management Effectiveness', American Management Assocation, Inc., 1981;

[9]. Narula M, article on 'Restructuring of Course for Development Linkage', University News, AIU pub. weekly, Apr. 13, 1992;

[10]. Shukla S, article on 'Higher Education and Higher Education Policy', UGC Journal of Higher Education, Vol, 15, Nos. 1-3, Monsoon spring 1989-90;

[11]. Sherlekar SA, 'The Principles of Management', Himalaya pub. Bombay, 1987;

[12]. The staff of Rohrer hibler \& Replogle, inc., The Managerial Challenge', Mentor Ex. Lib. Pub;, 1981. 